\title{
Reduction in air pollution using the 'basa njengo magogo' method and the applicability to low-smoke fuels
}

\author{
Lukas J Le Roux \\ Materials Science and Manufacturing, CSIR, Pretoria
}

\author{
Mark Zunckel \\ Shirley McCormick
}

from the low volatile coal. The method of lighting the fire does not have a significant effect on the $\mathrm{SO}_{2}$ emissions. The Basa njengo Magogo method of ignition uses approximately $1 \mathrm{~kg}$ less coal to reach cooking temperature than the traditional bottom-up method. At a cost of approximately $R 1.00$ per kilogram of coal, this translates into a cost savings of approximately $\mathrm{R} 30$ per month.

Keywords: air pollution, Basa njengo Magogo, lowsmoke fuels, cooking temperature

\section{Introduction}

To support the findings of the largely qualitative studies aimed at demonstrating the Basa njengo Magogo alternative fire lighting method, the CSIR was appointed by the DME to conduct experiments under controlled laboratory conditions to gather quantitative data on the reduction in particulate emissions associated with the Basa njengo Magogo method of lighting coal fires. The CSIR was further contracted to assess whether the Basa njengo Magogo technology was viable with low-smoke fuels such as devolatilised coal.

This paper compares the characteristics of fires ignited, using the Basa njengo Magogo technology with typical coal and three low-smoke coals. It also makes comparisons with typical coal used in the conventional bottom-up ignition method. All experiments were done at least five times to ensure consistency. The time to boil one litre of water was also determined during these experiments but is reported elsewhere (Le Roux, et al., 2005).

\section{Experimental methodology}

\subsection{Experimental equipment}

The monitoring equipment, mbawula (a homemade brazier) and ducting for gas extraction used 
(see Figure 1) in this project is the same as those described in Le Roux et al. (2004).

\subsection{Fuels that were tested}

The following fuels were purchased:

- D-grade coal, with a volatile content of $23.5 \%$, from Pretoria Coal Company, referred to as Coal (when tested using the bottom up method) and BNM Coal (when tested using the Basa njengo Magogo method);

- Low volatile coal, with a volatile content of $20.8 \%$, from Slater Coal, Dundee, referred to as Slater Coal;

- Anthracite (open cast mine), with a volatile content of $10.6 \%$, from Afriore, referred to as Anthracite OC;

- Anthracite (underground mine), with a volatile content of $12 \%$, from Afriore, referred to as Anthracite UG.

Six kilograms of fuel were used for each experiment; for the Basa njengo Magogo method, one kg of this was used on top and five $\mathrm{kg}$ at the bottom. In addition, wood was purchased and prepared by chopping into smaller pieces to fit in the mbawula.

Samples of the fuels and wood were sent to Coal and Mineral Technologies (Pty) Ltd (a subsidiary of the SABS) for proximate, ultimate and sulphur content and $\mathrm{CV}$ determinations.

\subsection{Particulate sampling}

All particulate emission measurements were done by means of iso-kinetic sampling in accordance with the method that is accepted by the then Department of Environmental Affairs and Tourism (DEAT), as published in CSIR Report No. CE-I93001, Method 2 (Albertyn, 1989) This method is based on features contained in US EPA methods (OAR, 1997), British Standards, German VDI methods and Japanese JIS standards.

The method also complies with the requirements of BS ISO 9096, (2003) 'Stationary Source Emissions - Determination of concentration and mass flow rate of particulate material in gas-carrying ducts'.

\subsection{Gas sampling}

Oxides of sulphur (SOx) were expressed as sulphur dioxide $\left(\mathrm{SO}_{2}\right)$. $\mathrm{SO}_{2}$ concentrations were determined by calculation, assuming that all the sulphur that is lost during the burn is converted to $\mathrm{SO}_{2}$. The initial

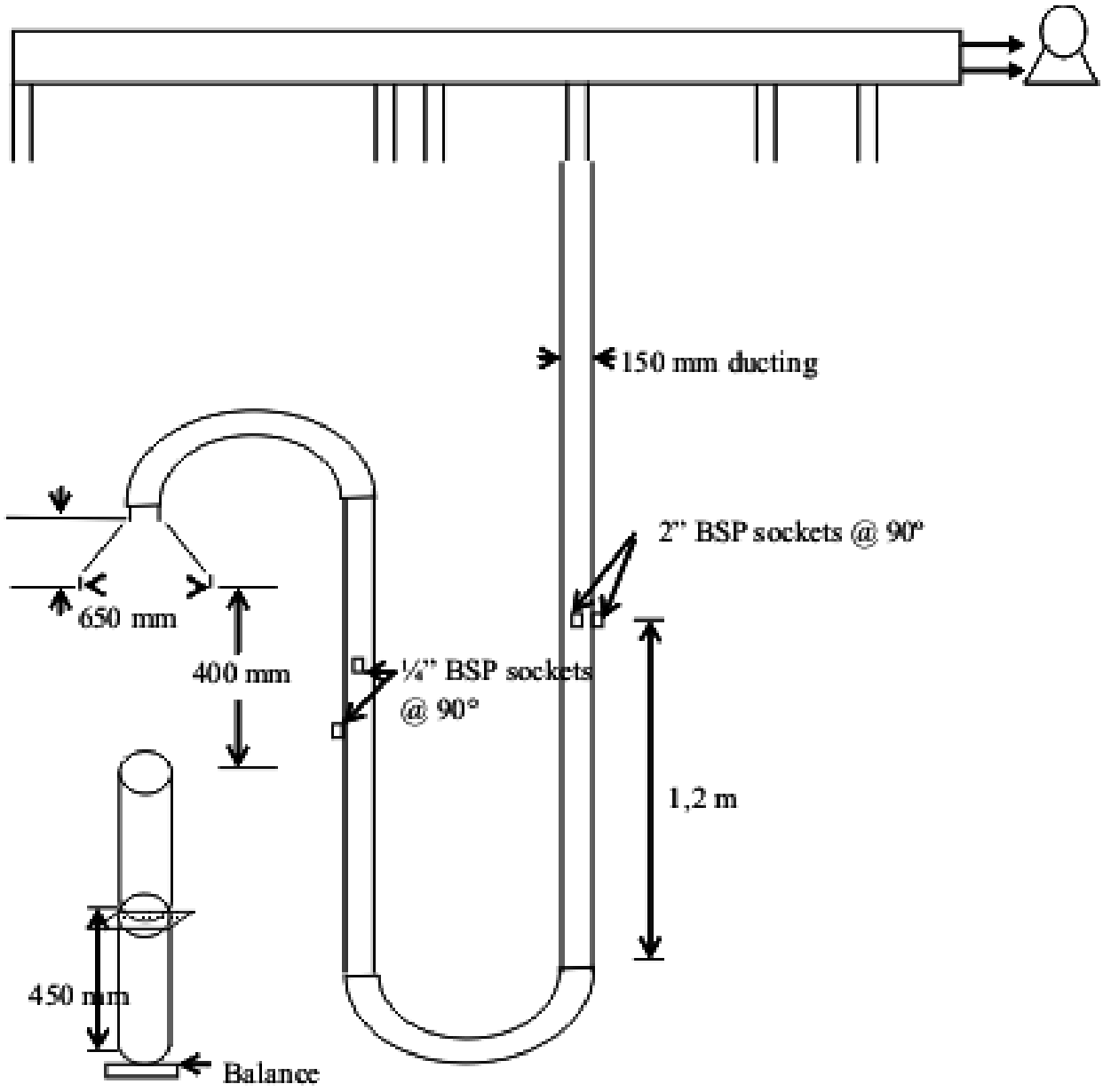

Figure 1: Setup for the low smoke fuel testing 

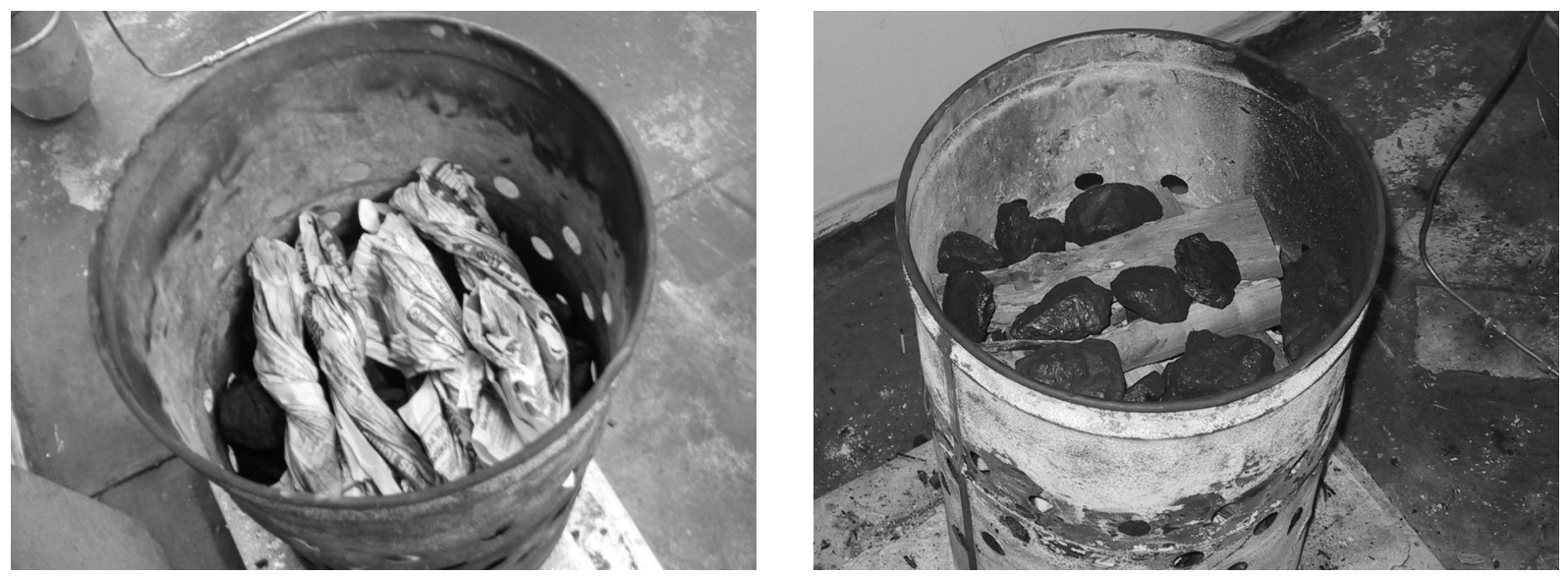

Figure 2: Fire prepared in the Basa njengo Magogo manner. The wood and a few coals are then put on top of the paper

sulphur concentration in the fuel and the residual sulphur content of the ash were used to determine the sulphur loss during the burn.

\subsection{Temperature}

The temperature was measured with a type ' $\mathrm{K}$ ' thermocouple that was placed just below the top steel grid (above the fire).

\subsection{Preparation for traditional method}

The fires for traditional D-grade coal were packed in the traditional way. Four double pages of a small newspaper were separately rolled and twisted, and put into the mbawula first. One kilogram of wood was added onto the paper. Care was taken to ensure that about $200 \mathrm{~g}$ of fine wood was added before the rest $(800 \mathrm{~g})$. Six kilograms of coal was added on top of the wood. The mesh and chimney were placed on top of the mbawula and the paper was lit. The iso-kinetic sampling also started at this point as well as the logging of the $\mathrm{CO}, \mathrm{CO}_{2}$, and temperature.

Iso-kinetic sampling was conducted for 1 hour before the water-boiling test was done. The chimney was removed after one hour when the smoke had subsided. The following day the ash samples were combined, milled, homogenised and sent for sulphur analysis.

\subsection{Preparation for Basa njengo Magogo method}

Five kilograms of coal and/or the low volatile fuels were added into the mbawula. Four pages of newspaper (separately rolled and twisted) were put on top of the coal. $200 \mathrm{~g}$ of fine wood and $800 \mathrm{~g}$ of coarse wood was added. One kilogram of coal was added on top of the wood. An example of a Basa njengo Magogo prepared fire is illustrated in Figure 2 . The mesh and chimney was put on top of the mbawula after the fire was lit. In all cases, the sampling started at this point. The chimney was removed after 10 minutes. Iso-kinetic sampling was carried out for 45 to 60 minutes. The ash was treated the same as for the traditional method.

\subsection{Batch mass}

All the burn samples comprised approximately $6 \mathrm{~kg}$ of the respective fuel and $1 \mathrm{~kg}$ of wood each.

\subsection{Time to cooking}

Time to cooking is the time that it took from the point when the fire was lit until the point where a person could use the fire for cooking. The time to cooking was taken from the mass loss vs. time curves at the point where the total mass lost equalled the mass of firewood added.

As can be observed from Figure 4, the rate of mass loss decreased significantly after the approximately $1 \mathrm{~kg}$ of firewood burned out after which it became virtually constant for more than forty minutes. The amount of coal used to reach the cooking time is used as an indicator of the cost of the conventional and Basa njengo Magogo fires.

\section{Results and discussion}

Each of the key parameters is discussed in this section as averages for the various fuels.

\subsection{Temperature and $\mathrm{CO}$ and $\mathrm{CO}_{2}$ emissions}

The characteristics of temperature and $\mathrm{CO}$ and $\mathrm{CO}_{2}$ emissions for the different fuels in the Basa njengo Magogo fires, as well as from the traditional bottomup coal fire are discussed here. Their variation during the fires is illustrated in Figures 3a and 3b.

\subsubsection{Coal (traditional method)}

Smoke was visible from the point when the fire was lit. The CO concentration increased and stayed at high levels until the flames started to 'penetrate' through the coals. At this point, the $\mathrm{CO}$ started to decrease, the $\mathrm{CO}_{2}$ started to increase and the tem- 

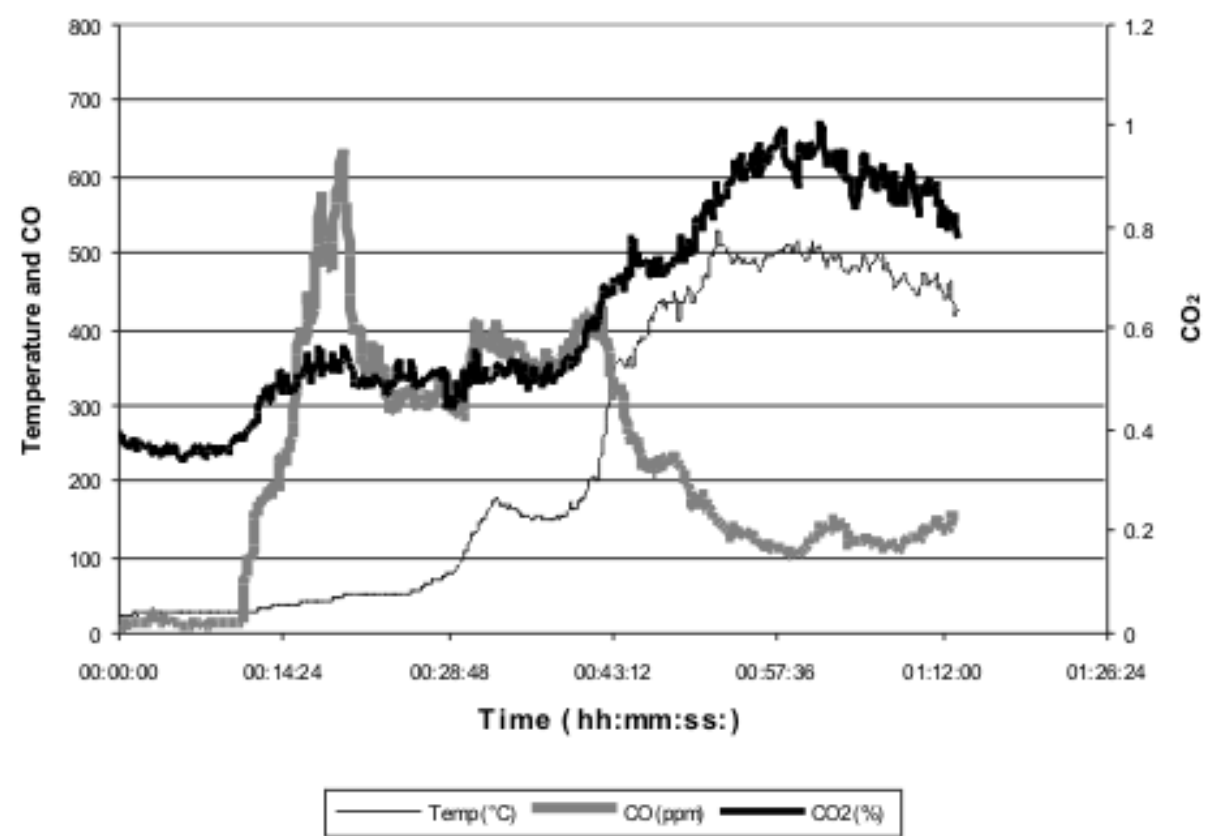

Figure 3a: Temperature, $\mathrm{CO}$ and $\mathrm{CO}_{2}$ for the traditional method

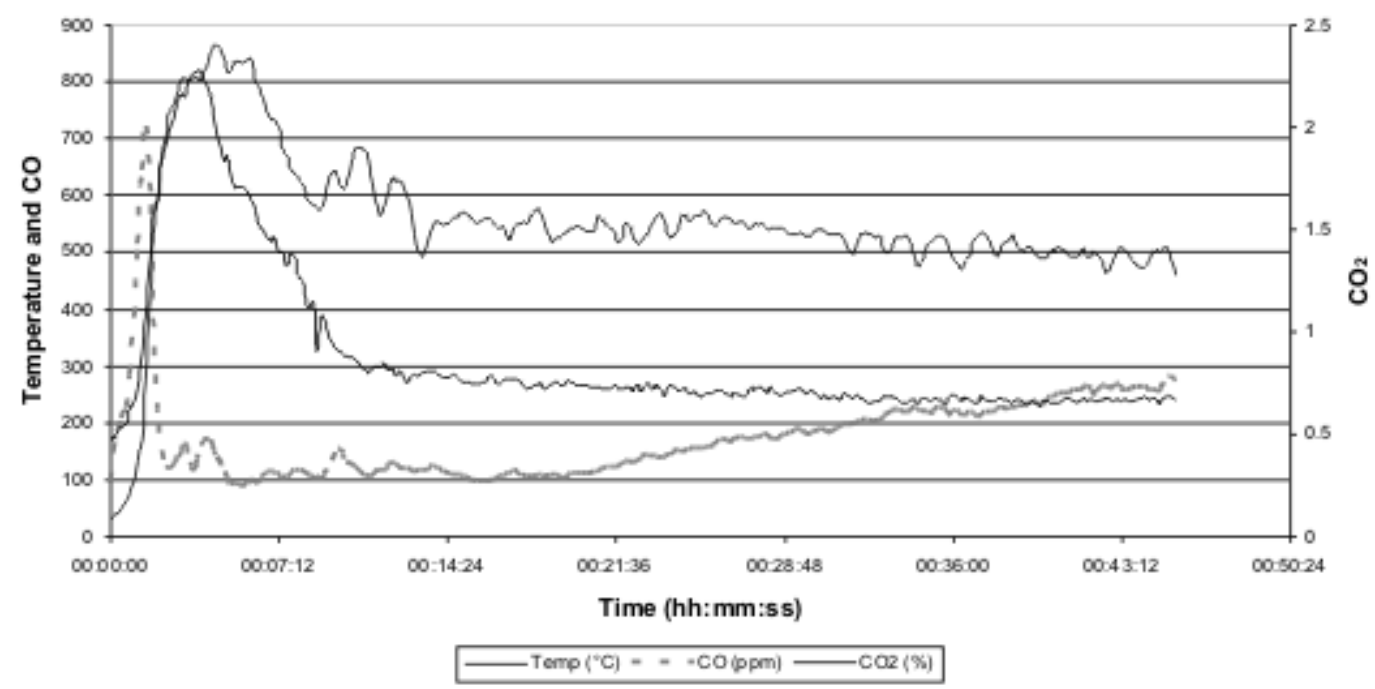

Figure 3b: Temperature, $\mathrm{CO}$ and $\mathrm{CO}_{2}$ for the $\mathrm{BnM}$ method

perature rose. This time was usually after about one hour at which time no visible smoke was emitted.

\subsubsection{Coal and anthracites (Basa njengo Magogo)} All of these fuels behaved in a similar way. Very little smoke was observed and the temperature, $\mathrm{CO}$ and $\mathrm{CO}_{2}$ profiles confirm the similar behaviour when using the Basa njengo Magogo method (see Figure $3 \mathrm{~b})$. After about two minutes, the $\mathrm{CO}$ concentration increased rapidly and then decreased after a further one minute, at which time there was a sharp increase in temperature. The $\mathrm{CO}$ decreased due to the conversion into $\mathrm{CO}_{2}$ (complete combustion), hence the increase in $\mathrm{CO}_{2}$ concentration.

\subsubsection{Slater coal (Basa njengo Magogo)}

This fuel showed different burn characteristics than any of the other fuels that were tested. Although the initial character was almost identical to the other fuels, the flames did not subside for about an hour. The emissions were higher than all the fuels tested with the Basa njengo Magogo method (see Figure 7). The final ash was also less than for the other fuels (more complete combustion).

Comparison of the temperature curves shows remarkable similarity between the four Basa njengo Magogo fires, all peaking within a few minutes of each other, within the first five minutes of ignition (see Figure 4). The coal using the bottom-up igni- 


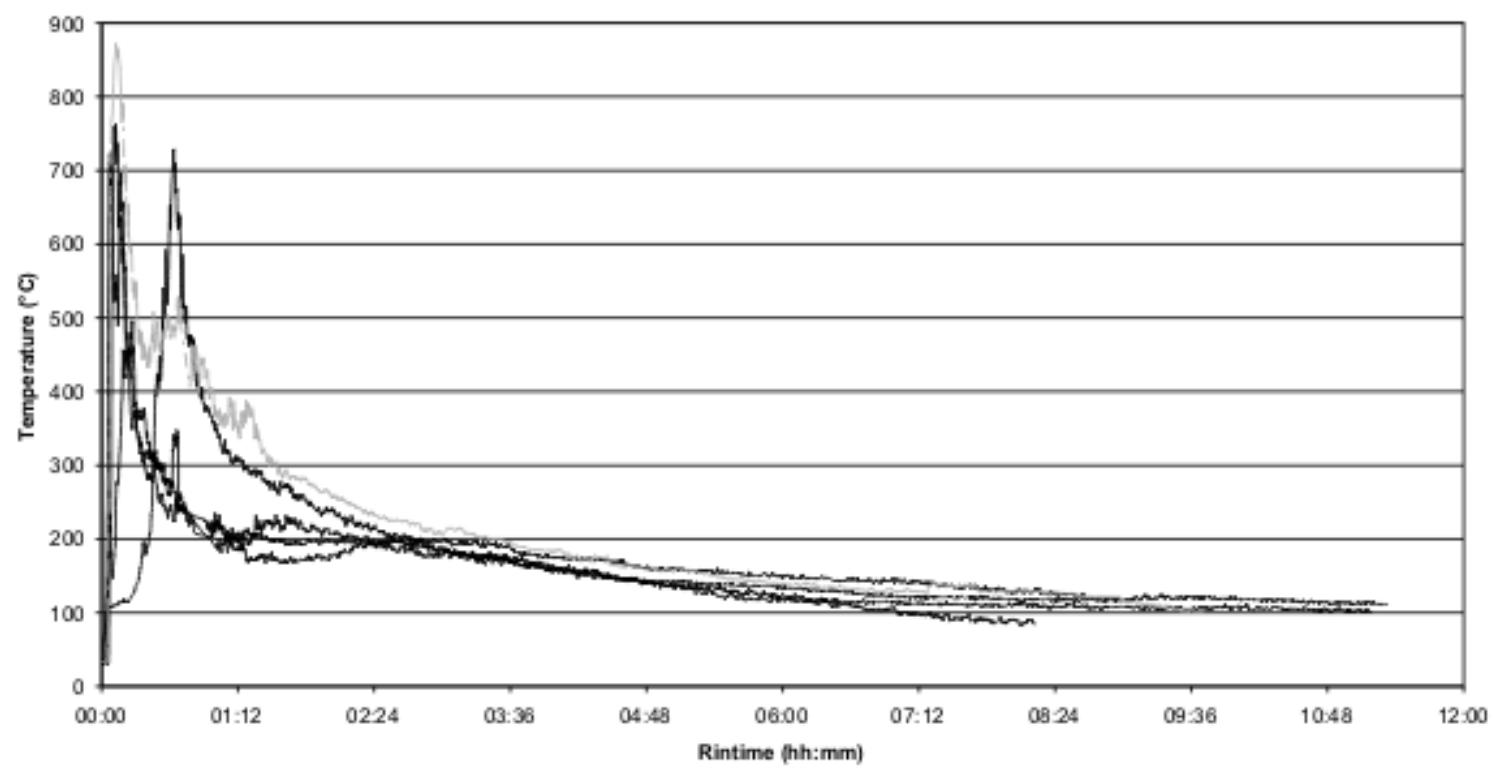

- Coal (BNM) - Caal (qradfional) - AntUG —AnNOC - - - Slater

Figure 4: Temperature variation during the four Basa njengo Magogo fires and the bottom-up ignited coal fire. The low values between $\mathbf{3 0}$ and $\mathbf{4 0}$ minutes coincide with the water boiling part of the experiment, when the temperature sensor was removed

tion method peaks later. After approximately 2 hours after ignition, the temperature from all the fires was very similar.

\subsection{Mass loss vs time}

When considering the different graphs of 'Mass loss vs. Time' (see Figure 5) over the first two hours, the following becomes evident:

- The traditional method of lighting a coal fire takes about 60 minutes before the smoke subsides and the fire is ready for cooking. At this time, approximately $2 \mathrm{~kg}$ of fuel have been consumed.

- If the Basa njengo Magogo method is used for any of the fuels, the fire is ready for cooking within 7 minutes. At this time, approximately 1 $\mathrm{kg}$ of fuel has been consumed.

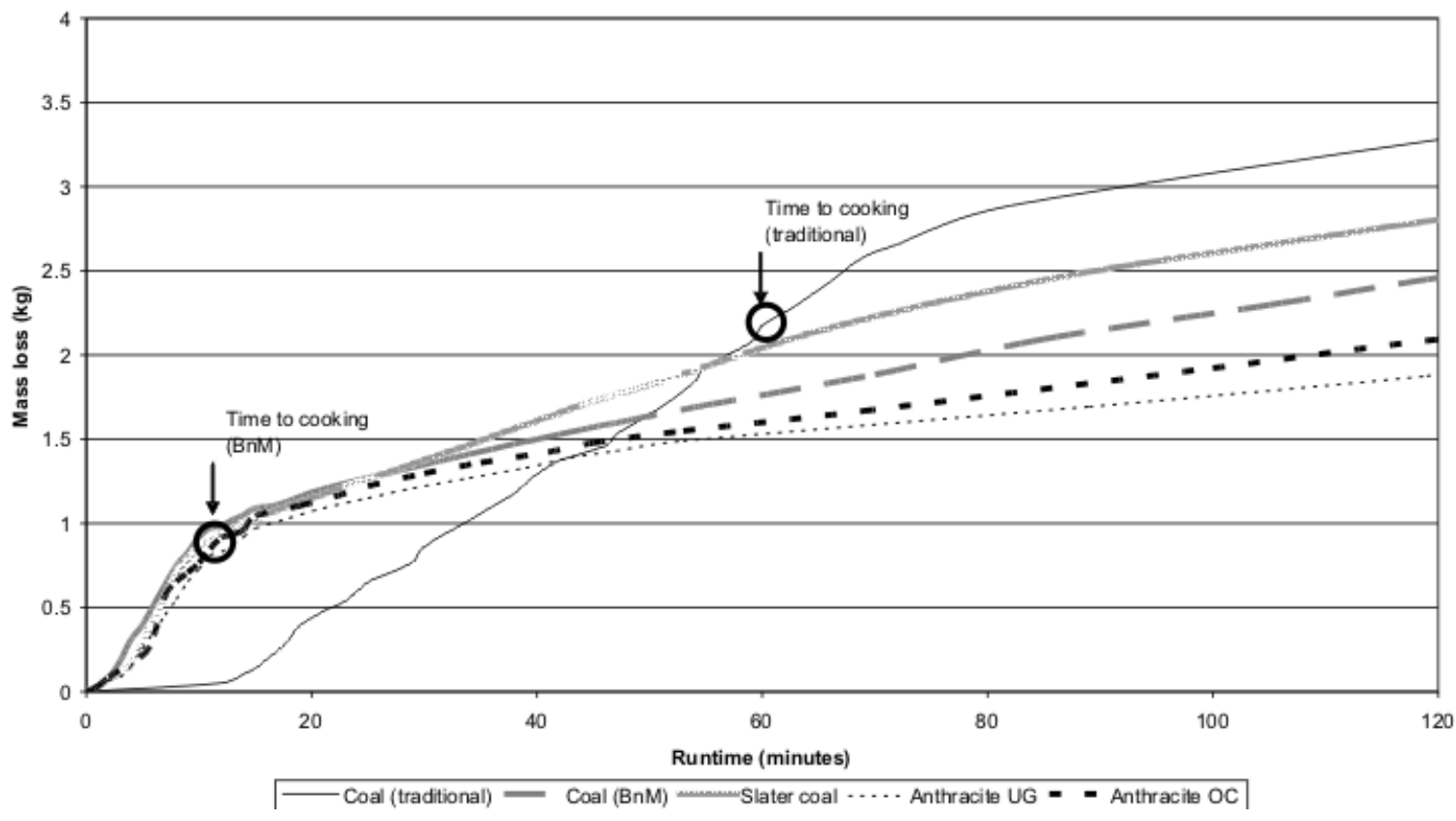

Figure 5: Mass loss versus time for the four Basa njengo Magogo fires and the bottom-up ignited coal fire 
Table 1: Summary of results

\begin{tabular}{lccccc}
\hline & Traditional method & \multicolumn{3}{c}{ BNM method } \\
\hline & Coal & Coal & Slater coal & Anthracite UG & Anthracite OC \\
\hline **TSP concentration (NTP) $(\mathrm{mg} / \mathrm{MJ})$ & 536.4 & 71.0 & 148.8 & 42.3 & 45.8 \\
\hline Time to cooking temperature $(\mathrm{min})$ & 55 & 11 & 11 & 12 & 13 \\
\hline $\mathrm{SO}_{2}$ emitted $(\mathrm{mg} / \mathrm{MJ})$ & 418 & 417 & 1104 & 650 & 736 \\
\hline Volatile matter & 23.5 & 23.5 & 20.8 & 12.0 & 10.6 \\
\hline ** Total solid particulates & & & & & \\
\hline
\end{tabular}

Table 2: Analysis of the different fuels (dry basis)

\begin{tabular}{lcccccc}
\hline \multicolumn{7}{c}{ Sample } \\
\hline Calorific Value & $\mathrm{MJ} / \mathrm{Kg}$ & Coal & Slater coal & Anthracite OC & Anthracite UG & Wood \\
\hline Inherent $\mathrm{H} 2 \mathrm{O}$ & $\%$ & 25.08 & 21.44 & 30.85 & 30.30 & 17.18 \\
\hline Ash & $\%$ & 3.3 & 1.6 & 1.8 & 1.2 & 7.1 \\
\hline Volatile Matter & $\%$ & 17.9 & 15.2 & 8.5 & 10.2 & 5.1 \\
\hline Fixed Carbon & $\%$ & 23.5 & 20.8 & 10.6 & 12.0 & 68.7 \\
\hline
\end{tabular}

Ultimate analysis

\begin{tabular}{llcccc}
\hline Carbon & $\%$ & 65.44 & 73.23 & & 46.02 \\
\hline Hydrogen & $\%$ & 3.31 & 3.87 & 5.21 \\
\hline Nitrogen & $\%$ & 1.50 & 1.74 & 1.93 & 0.69 \\
\hline Total Sulphur & $\%$ & 0.53 & 1.50 & 1.60 & 0.05 \\
\hline Oxygen & $\%$ & 8.02 & 2.86 & & 35.83 \\
\hline
\end{tabular}

\subsection{Time to cooking}

The four Basa njengo Magogo fires all reached the time to cooking point between 5 and 7 minutes after ignition (Figure 5). The bottom-up coal fire reached cooking temperature after some $60 \mathrm{~min}-$ utes.

\subsection{Particulate emissions}

As expected, the particulate emissions measured in the Basa njengo Magogo tests were significantly lower than for the tests for the traditional way of lighting the fires. A visual comparison of the resultant particulates (smoke) is shown in Figure 6.

Particulate emissions per $\mathrm{MJ}$ of total input energy were low for the two anthracite fuels and for DGrade coal using the Basa njengo Magogo methodology (see Figure 7). Emissions for the Slater low volatile coal were somewhat higher. Particulate emissions from the coal fire ignited in the bottomup manner were more than 3 times those of any of the Basa njengo Magogo fires.

Particulate emissions from coal in the Basa njengo Magogo fires are $87 \%$ less on average than the particulate emission from coal in the conventional bottom-up fire (Figure 7). A reduction in particulate emissions of between $92 \%$ and $78 \%$ was observed for all the fuels when using the Basa njengo Magogo methodology.

\subsection{Sulphur dioxide}

Emissions of sulphur dioxide are related to the sulphur loss on burning of the respective fuels. The highest emissions were measured for the Slater low volatile coal, followed by the two anthracites (see Figure 8). $\mathrm{SO}_{2}$ emissions from the D-Grade coal in the Basa njengo Magogo and bottom-up methods were identical. The $\mathrm{SO}_{2}$ emitted is a direct consequence of the sulphur in the fuel as well as the burning characteristics of the different fuels. Although Slater coal had a lower sulphur content than the anthracites, more $\mathrm{SO}_{2}$ was emitted due to more efficient conversion of sulphur to $\mathrm{SO}_{2}$.

\subsection{Cost savings}

Approximately $2 \mathrm{~kg}$ of coal plus firewood is consumed before cooking can begin using the traditional ignition method. This compares with approximately $1 \mathrm{~kg}$ of coal plus firewood for the Basa njengo Magogo method (Figure 5). This means that about $1 \mathrm{~kg}$ less fuel can be used to get the same useful heat.

The market price of D-Grade coal is about R1.00 per kg (Pretoria Coal Co.). The implication is that approximately R1.00 is saved per fire when using the Basa njengo Magogo method. On the assumption that one fire is made each day, particularly in winter, a saving of approximately R30 per month can be made. 

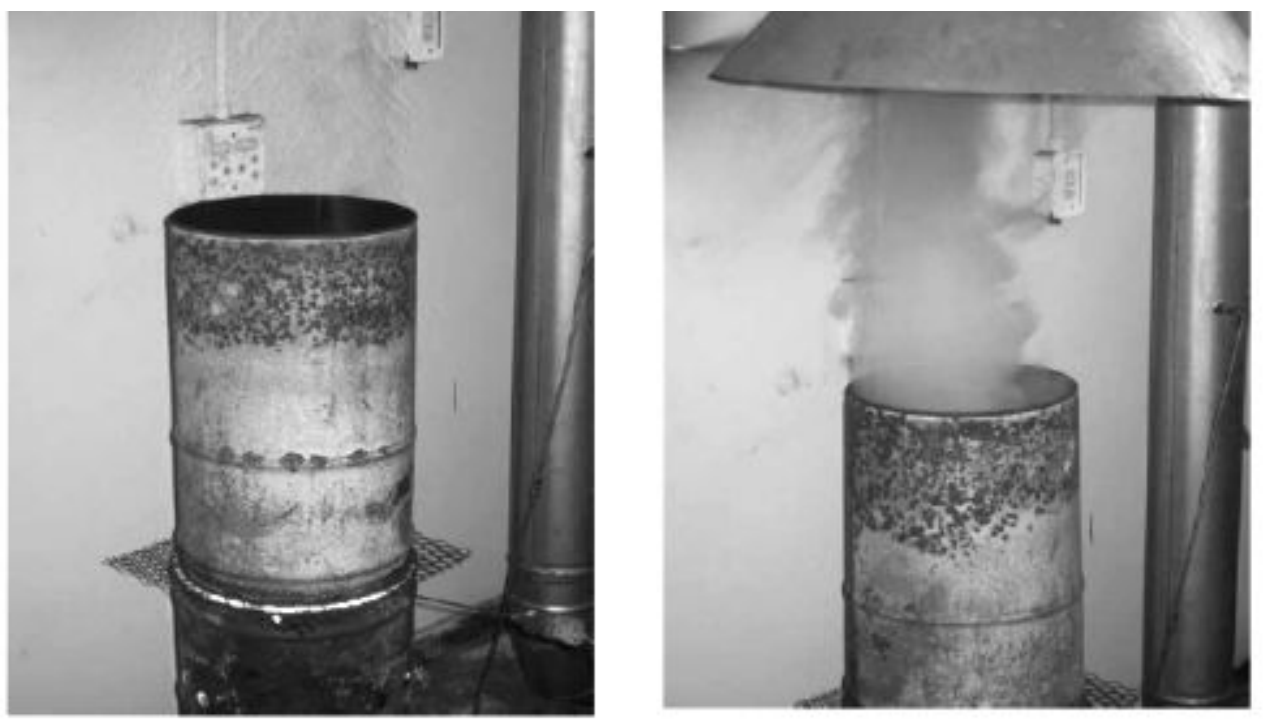

Figure 6: Comparative smoke emissions from the Basa njengo Magogo fire (left) and a fire ignited with the bottom-up method (right), using traditional D-grade coal

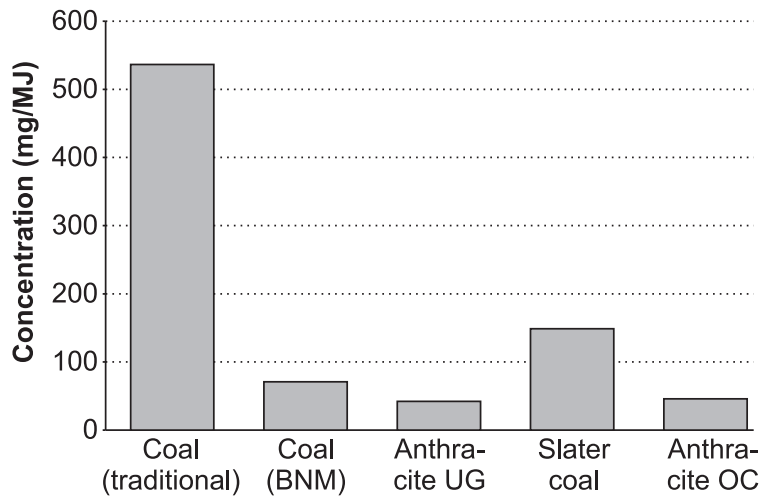

Figure 7: Particulate emissions for the four Basa njengo Magogo fires and the bottom-up ignited coal fire

\section{Conclusions}

This experiment was conducted using traditional DGrade coal in both the conventional bottom-up and the Basa njengo Magogo ignition techniques. Three low volatile fuels were also assessed using the Basa njengo Magogo method.

All four fuels using the Basa njengo Magogo method recorded similar times of between 11 and 13 minutes from ignition of the fires to reaching cooking temperature. The bottom-up fire for conventional D-Grade coal reached cooking temperature after 55 minutes.

Particulate emissions from all the Basa njengo Magogo fires were similar and up to $92 \%$ lower than the particulate emissions from D-Grade coal in the bottom-up fire, depending on the fuel used.

$\mathrm{SO}_{2}$ emissions from the two D-Grade coal fires were the lowest and were identical for the traditional and BnM methods. The BnM method of lighting a fire does not have any influence on the $\mathrm{SO}_{2}$ emissions.

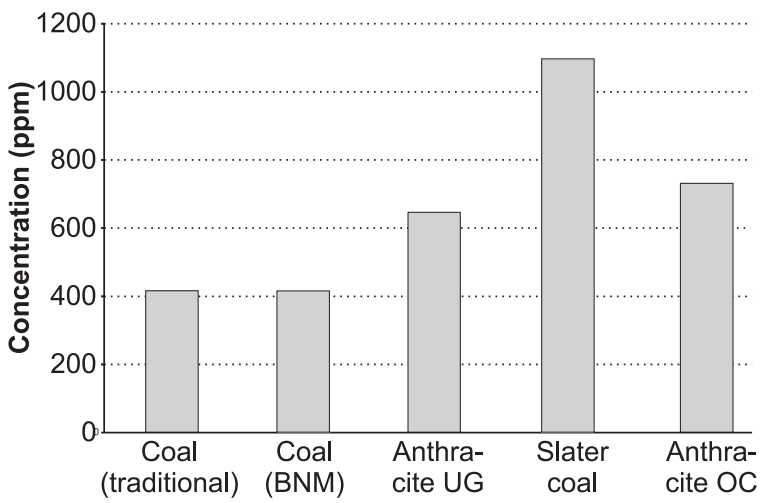

\section{Figure 8: $\mathrm{SO}_{2}$ emissions for the four Basa njengo Magogo fires and the bottom-up ignited coal fire}

The Basa njengo Magogo top-down ignition uses approximately $1 \mathrm{~kg}(20 \%)$ less coal to reach cooking temperature than the traditional bottom-up method. At a cost of approximately R1.00 per kilogram of coal, this translates into a cost saving of approximately R30 per month. South Africa produces 246 million tonnes of coal (www. nationmaster.com/country/sf/Energy) and uses 178 million tonnes per year of which 2.5 million tonnes is for household use. A $20 \%$ saving translates to 370 million rand per year.

\section{Acknowledgements}

- The DME for sponsoring the project.

- Mrs Mmathabo Murubata of Palmer Development Consulting for training.

- Eddie Erasmus, Vongani Nkhwashu, Alphius Bokaba and Rietha - Oosthuizen of the CSIR 
for technical support.

- Slater Coal and Afriore for the supply of coal samples.

\section{References}

Albertyn, C.H., 1989. Isokinetic Sampling. CSIR Report No. CE-I-93001, Method 2.

Le Roux, L. J., Cilliers, K. F. P. and Van Vuuren, D. S., 2004. Low-Smoke fuels Standard Testing and Verification. Final Report to the Department of Minerals and Energy. CSIR Report No. 86DC / HT776.

Le Roux, L. J., Zunckel, M. and McCormick, S.G., 2005. Laboratory Controlled Quantitative Information about Reduction in Air Pollution using the 'Basa njengo Magogo' methodology and Applicability to LowSmoke Fuels. CSIR Report No. ENV-D-C 2005-004.

Office of Air and Radiation (OAR) database at http://tnwww.rtpnc.epa.gov/ naaqsfin/pmfact.htm, 1997. US EPA fact sheet.

Palmer Development Consulting, 2003. Basa njengo Magogo Pilot Study: Orange Farm. Department of Minerals and Energy: Pretoria.

Schoonraad, P.J. and Swanepoel, P.A., (2003). Evaluation Report. Pilot implementation of Basa mama as a method of igniting a coal fire. Report ZAQ/I/05.

Standard BS ISO 9096, 2003. Stationary Source Emissions - Determination of concentration and mass flow rate of particulate material in gas-carrying ducts

Received 23 January 2009; revised 18 June 2009 